\title{
Impact of Dividends Announcements on Stock Returns Evidence From Karachi Stock Market
}

\author{
Hasnain Manzoor ${ }^{1}$ \\ Department Of Management Sciences Mohammad Ali Jinnah University Islamabad, Pakistan
}

\begin{abstract}
This study examines the reaction of stock returns in relation to earnings dividend information releases using data on the Karachi Stock Exchange. Using the event study method, the speed of reaction of the market to annual earnings information releases for a sample of 114 firms listed on the Karachi Stock Exchange. Significant abnormal price reactions around earnings announcements suggest the earnings announcements contain valuerelevant information. Event window of 41 days, 20 days before and 20 days after the announcement is used. Event day is represented by (0). Estimation window is used 230 days before the event window. Findings indicate that changes in stock prices in Pakistan in relation to earnings and dividend announcements is not random, but follow the pattern, which allows the negative abnormal returns can be earned from trading around earnings and dividend announcement date. Analyses also concludes that positive and negative earning information disclosure are unable to influence the stock market efficiency, and therefore cannot fully reflect the changes on the stock price, investors can get the abnormal returns by using this earning information during whole event window. Finally, Karachi Stock Market reacts inefficiently on the release of information of earnings and dividends announcements.
\end{abstract}

Keywords: earnings announcements; increase of earnings; decrease of earnings; dividend announcements; abnormal returns; event studies; Karachi Stock Market.

\section{INTRODUCTION}

Financial market plays an important role in the development of the economy of any country. One of the components of financial market is capital market and Ekezie (2002) noted that "the market which deals with the lending and borrowing activities in long-term loanable funds". Akingbohungbe (1996) said, in this market medium and long term loan can be achieved. Mbat (2001) described it as these long term surplus funds are used to fulfill the economic deficit. It has very intense implication for the socioeconomic development of any nation. Companies can raise funds through issuing the equity or debenture/ bonds to manage the financial requirement of production. Equity has perpetual life where debentures/ bonds are issued for a longer period of time, usually five to twenty five years. This is very essential for companies as well as for the Government to raise the long term funds (Nwankwo, 1991).

The stock market is the center point of traders, purchasers and sellers who deal in securities of different forms and life duration. When an investor invests in the market to earn access money, he also outperform or beat the market. If the market is working efficiently, it means there is no resistance in doing business (Mabhunu, 2004). Previous history of prices and volume is available and price responsive information is both appropriate and correct, therefore information distribution is extensive and quick.

Beginning to the influential work by Beaver (1968) and Ball \& Brown (1968), reaction of stock market regarding disclosure of information is very huge and covers a different variety of information disclosure such as earning announcement, dividend announcements, stock splits, macroeconomic policy alteration and merger announcements. One area that has received much attention is the influence of income disclosure on stock prices. Most of these areas are practices in the UK, at a reduced level are based on the United States. The market share of earnings and related information to respond quickly and efficiently as they contain information are more consistent hypothesis valuable evidence presented in the studies.

Investors purchase securities with these expectations that it will generate return in the future. They tried to collect the information which other investors have not. When new information comes into the market the investors behave

${ }^{1}$ Corresponding Author: hasnain4343@yahoo.com 
differently. Some of these react instantly and some analyze it on the basis of historical data. Market efficiency is linked with certainty in prices of securities which follow the investor expectations. The Efficient Market Hypothesis $(\mathrm{EMH})$ has found widespread use in research that transactions with a consideration of practical models, new issues, stock splits and prevent the performance of mutual fund performance in relation to the understanding. There are many evidences which are consistent with the previous studies that market is a strong form efficient, but in some cases due to emotional and cognitive biases, market anomalies exist in prices and returns, as a result which shows that market always not perform efficiently.

There are different reasons and logics are available that behavior of developed and developing countrie's stock markets is different. Markets of developed countries are highly sensitive, liquid and respond to the information very quickly. But the stock markets of developing countries showed different behavior, which mostly seemed unsophisticated and illiquid, poor performance of rules and regulations and different operational and institutional strategies (Osei, 2002).

\section{THE EFFICIENT MARKET HYPOTHESIS (EMH)}

One of the major theme in finance literature is the concept of stock market efficiency and how different information is reflected in stock prices. The Efficient market hypothesis (EMH) suggests that competition between investor's abnormal profits derives when prices higher than their "fair values." This means that prices should consider market information. The capacity of the market is calculated when information is incorporated into price determination. Fama (1970) declared that these are enough but not the compulsory surroundings for efficiency are; there are no transaction costs in securities trading, all information is available to market participant has zero cost, fixed investment policy and market participants agree on the meaning of current information and the current price and future price of each security distribution.

Fama (1970) classified the information items into three levels depending on how quickly the information is reflected into price;

(1) Weak-form EMH

(2) Semi-strong form EMH

(3) Strong-form EMH

Weak form efficiency is the less accurate form of efficiency, there is one possibility of adjustment of historical prices is a subset of publicly announced information. It pursues if there is any alteration in share prices it cannot be predicted from previous public information or from historical data, we cannot predict future prices of the stocks. It is generally assumed that news arises randomly and share prices should also be move in random form.

It states that: In an investment plan, on the basis of fundamental analysis no access returns can be earned. The second major argument is that from technical analysis access return cannot be earned. To analyze it, in time series data of stock prices it is enough to apply statistical techniques.

Semi strong form efficiency is defined as prices respond to all public information and on the basis of this information no abnormal return can be obtained. Tests of semi-strong form efficiency suggests that investors cannot get a higher return on this information which is publicly available, such as the annual financial reports of commercial units, earnings announcements, stock split announcements, dividend announcements and repurchase of stock announcement (Fama, Fisher, Jensen, \& Roll, 1969).

Semi strong form EMH explains: If the information comes in the market, the prices change immediately in a fair pattern and on the basis of this information an investor cannot get a surplus return. It also states that on the basis of fundamental analysis no one can achieve access return. If we want to check the efficiency of the market, then there should instantaneous adjustment in size of previous prices. If these prices follow the pattern in this adjustment, this reflects that investor had understood this information in a subjective and inefficient way.

Strong form efficiency of efficient market hypothesis (EMH) states: Market price of shares reflects all public and private information and no investor can get access return. To examine the strong form efficiency, there is a requirement of the existence of that market where investor constantly does not obtain access return for a longer period of time. If the subject of insider trading is introduced, in which the investor trading is not available to the public. Then the concept of strong form efficiency fails. Fund managers have consistently beaten the market; it cannot be described as strong form efficiency. 
The main purpose of the dividend is to increase the shareholder wealth. It may be dividend or capital gain. For investment decision dividend policy is an important factor. There are a number of factors which affect the dividend policy decisions of a firm such as investor preference, earnings and investment opportunities, flotation costs, signaling, stability and Government policies. It is also important for lenders, manager and other stakeholders. There are different types of dividend policy and selection of most suitable dividend policy is important for companies because on the basis of these information's investors invest in the stocks. For the companies it is important because in future flexibility is available to invest in future projects which depends upon the amount of dividend which have been paid. The dividend may convey information about the health of the company and this information will affect the stock prices. Paying large dividends reduce risk and this influence stock prices (Gorden, 1962) and this is a proxy for future earnings (Baskin, 1989).

Juma'h \& Pacheco (2008) explained that sometimes financially strong companies do not pay dividend while the other which are not in a better financial position, they pay dividends. Also explained that those companies which pay dividend mostly large in size, more profitable and liquidity ratios are high. Companies in Malaysia are paying dividend, whether these are generating profit or not.

Dividend plays a vital role in minimizing or maximizing the conflicts between shareholders management. When a company pays dividends to its shareholders, it gives them surplus money and the remaining portion of cash spends into those projects which have positive NPV (Black, 1976) and (Easterbrook, 1984).

When companies change the policies of dividend and are unexpected for shareholders and other stakeholders, it creates a signal into the public which may affect the market value of the company. So managers stay away from changing the dividend policies because they knew about its effect on stock prices, which actually change the value of the company (Lintner, 1956). Michaely et al. (1995) explain that in the USA the companies don't announce dividend, decrease value by $7 \%$ and those companies which announce dividend their value appreciated by $3 \%$ on event day.

There are many advantages and disadvantages of paying the dividend. When companies have paid dividend to its shareholders it may be possibility to invest into a new project, but company has no surplus money for investment which results that loose this opportunity. Most young firms which are in growth stage do not pay dividend and they collect money from external sources. Big firms which have a moderate growth rate, some portion of money invests into shareholders and remaining portion save as retained earnings for further investment. Those firms which are in maturity stage and growth rate is very slow and rare investment opportunities, then free cash flow have a tendency to grow and payout ratio also maximize, both through dividend and share repurchases, it decreases the agency problem of maintaining surplus cash (DeAngelo, 2006).

\section{SignAling TheORY}

This theory is based on information asymmetry between insiders (managers) and outsiders (investors). It states that the financial decisions of the corporations are signals that are sent by managers to investors so as to shake them up. Typically, one party, the sender, must choose whether and how to communicate (or signal) that information, and the other party, the receiver, must choose how to interpret the signal. So here discussion is about the signal of the company, when a company announces earnings, a signal creates in the market. This signal may be positive or negative. Whenever a bad news come in the market, capital market immediately responds to its stock prices and drop down immediately to the point where all securities have zero net present value and returns of securities are in accordance to risk adjusted rate of return. However market may over react to new information and prices drop down more than required level and then gradually moves up. According to Woolridge (1983) and Nissim and Ziv (2001), firms with good projects keep themselves different from bad firms by releasing signals to the market about their firm values.

\section{Cash Flow Related To Signaling Theory}

This theory is developed by Bhattacharya (1979), John and Williams (1985) and Miller and Rock (1985) which explain, an increase or decrease dividend express positive or negative information about the current or future cash flows, It also documents that these signals are sent by the manager of the company to the investor deliberately which may not necessarily bring the authentic scenario of the corporation. 


\section{DIVIDEND IRRELEVANCE THEORY}

Miller \& Modigliani (1961) proposed a dividend irrelevance theory where they showed that in a perfect capital market (where there is no personal or corporate tax, no transaction cost, no issuance cost, no individual investor whose total share can affect the share price and where companies have a fixed investment policy), the value or the share price of the firm will not be affected by the selection of its dividend policy. According to them, only the determination of market value or share price of the company is an investment and operating decisions that generate cash flows. The dividend is just a way to distribute the cash flow among investors that can easily be offset by other financing activities such as sales of new common equity share (Contemporary Financial Decision). They put forward that an increase in dividend entails capital loss to the existing shareholders, which actually offset each other and investor perceive a positive change in the dividend as the trade-off between current income and future selling price. Even though, the question could well be raised about the validity of perfect capital market, which ultimately questions the validity of the M-M model. However, this theory provides the base for later theories that deal with the imperfect capital market as in real world Capital market.

\section{AgenCy COST THEORY}

Jensen \& Mekling (1976) puts forward the idea of agency cost theory which can also be used to demonstrate predictions regarding the relationship between dividend policy and share price reaction. According to them, managers might use excess funds of the company for their personal benefits due to the separation of ownership from control where as a regular cash payment make sure that the manager do not have that extra amount that could transfer to their account. If manager announce fewer dividends, they have higher access to companies internally generated funds which would increase the chance of allocating a higher amount of company resources to their own funds. Therefore, this theory asserts that a decrease in dividend payout is related to the decreasing equity value of the company which actually has a negative effect on the share price of the company (Stephen A. Ross, 2007).

\section{BIRD IN HAND THEORY}

This is a pre Miller and Modigliani theory which states that due to information asymmetry and uncertainty, dividends are valued in a different manner as compared to retained earnings or capital gains. This theory held that firms due to uncertainty of cash flows in future prefer to pay out dividends then to retain the earnings. This reduces their cost of capital or required rate of returns and fevers the goodwill of the company.

\section{SigNifiCANCE OF THE STUDY}

There have been a number of studies conducted on earning and dividend announcements in different developed and developing stock markets. This study attempts to establish an impact of the dividend announcement on non-financial sector companies of Pakistan. Most of the studies have been conducted for the data from 2005 to 2008 in different countries of the world. However the purpose of this study is to find the impact of announcement of earnings as well as a dividend on stock returns on recent data for the period of 2008 to 2012. Large data sample of 114 firm is used. Therefore, it is to believe that this study would be able to provide valuable insights to the existing knowledge of this particular topic. The findings of the study would be useful for investors, non-financial sector company's shareholders, financial institutions and related Government departments. This is also valuable for policy makers when markets are crashing and profits decreased how they can increase shareholder wealth and will provide precious approaching to shareholders in our country.

\section{ORganization Of The PAPER}

The rest of the study is organized as follows. The next chapter 2, discusses the literature review of previous studies. Chapter 3 outlines the research methodology while Section 4 presents the empirical results \& discussion. Finally, chapter 5 provides conclusion and policy recommendations.

\section{LiterATURE REVIEW}

Early research document evidence of the association between security returns and the release of announcements of company earnings, dividends, issues of new shares and stock splits (Ball \& Brown, 1968; Beaver, 1968; Fama et al, 1969). The main weakness of these initial studies was their failure to isolate the effects of earnings changes from release of other information, due in part, to the use of monthly and weekly data.

Miller \& Modigliani (1961) said there is no effect of dividend on stock prices, whether company pay dividend or not. But on the other side a contrary argument given by Gordon (1963) explained dividend is relevant and it affects 
the market price of shares of the company. A third argument by Black \& Scholes (1974) which explained there is no link between dividend policy and stock prices and there are other factors which affect the prices like the decisions of investors that whether they invest in high or low yield securities. So different studies and literature is available to explain this relationship, whether there is any relation exists between dividend announcement and stock prices.

Akbar \& Baig (2010) concluded the reaction of stock prices to the cash dividend announcement which was statistically insignificant. But the average abnormal return and cumulative abnormal returns for dividend announcement were statistically significant which suggest a positive reaction. Stock dividend was not taxed and was resorted to by firms when cash needed high and future operations require expanded equally capital base. Further capital gain in Pakistan equity market was not taxed. Hence, stock dividends were alleged favorably by investors in the KSE. They used the sample of 79 firms listed on Karachi Stock Exchange for the period of 2004 to 2007.

Consistent with the results of Ahmed, Ashraf \& Ahmad (2013) conducted their study in two Stock markets of India for the period of 1999 until 2004. One was National Stock Exchange and other was Bombay Stock Exchange and found both Stock markets are inefficient.

Adelegan (2003) found that before 30 days and after 25 days of the announcement of dividend, returns of the market are significant positive. Which means this Market is not semi strong form efficient. Azhagaiah \& Sabari (2008) explained the impact of dividend on shareholder wealth. This study was conducted in an organic chemical sector in India for the period of 1996 until 2006. Results showed that there is a significant positive relationship between dividend and shareholder wealth.

Campbell (2009) conducted his study to examined the impact of a stock dividend on abnormal returns. He suggested that the stocks of those companies which are traded more frequently, their returns are significant and positive and those stocks which are not traded commonly their abnormal returns are insignificant. Similarly Travlos, Trigeorg \& Vafeas (2001) explained the effect of stock and cash dividend on the Cyprus Stock Exchange and found that when companies announce dividend, whether it is cash or stock dividend, a signal is created in the market which affect the returns of the companies. Announcement of dividend is very important for company survival and shareholders feel delighted when they receive a dividend. After the announcement of dividend investors and traders invest in the companies for better rate of returns and this announcement shows the health of the company, whether it will survive or not, also the growth and investment opportunities.

Scott \& Keith (1996) found there is positive impact of the dividend announcement on stock prices and this announcement give more information to the investors about the company position. Dharmarathne (2013) conducted his study in the Colombo Stock Exchange and found that prices react positively in this market and investors of this market show positive behavior with the announcement of a dividend also found that Colombo Stock Exchange is semi strong form efficient.

There are some contradict arguments by Mamun, Hoque \& Mamun (2013) founded in Dhaka Stock Exchange is their appreciation due to dividend announcement or not? They found there is no effect of pre and post announcement of dividend on stock prices. Ali \& Chowdhury (2010) for the banking industry and found there is no impact of the dividend announcement on stock prices of commercial banks of Bangladesh. Because their insider trading and some other factors play an important role in not conveying any information towards the prizes.

Irum, Rafique \& Hassan (2012) investigated the impact of dividend on stock prices. The study was conducted in four sectors of Pakistan economy for the period from 2005 to 2010. They found dividend announcement have no positive and significant impact on stock prices. So the Karachi Stock Exchange showed efficient behavior with respect to these four sectors which were observed under this study.

There are number of studies have been conducted in different developed and emerging stock markets of the world. Different results and argument have been seen in previous literature about the earnings and dividend announcements. Different stock markets reacts differently on such announcements about earnings and dividend information. Some of these shows efficient behavior and some inefficient on release of this information.

On the basis of the previous literature following hypothesis are developed:

\section{HYPOTHESIS}

Given the depth of information available about the stock prices from Karachi Stock Exchange (KSE), the null hypothesis is that earning announcement, positive or negative earnings and dividend announcement have no significant impact on stock price movement. 
$\mathrm{H}_{0}$ : Dividend announcements have insignificant impact on stock returns.

$\mathrm{H}_{1}$ : Dividend announcements have significant impact on stock returns.

\section{DATA AND METHODOLOGY}

In this study daily closing price, annual earnings announcement dates and dividend history has collected for a sample of firms listed on the KSE for the period of 2008 to 2012. The sample is selected on the basis of firms only required financial and market information. Thus stocks with insufficient data position, either as a result of nontrading or inefficiency of financial and market information, removed from the sample. Also, most companies in Pakistan from this sample announce their earnings quarterly, but in this study, these selected on an annual basis, increase or decrease earnings from last year and annual dividends also. For earnings announcement this sample consists of 114 companies from 32 sectors which are selected on three basis. First, above mention companies have been remained the part of KSE from previous ten years, second, foreign portfolio investment have incorporated in these companies and third, these are large in the sector. But these all are not paying dividend throughout the data period. Earnings per share is used to analyze the increase or decrease of earnings. The sample is divided into three categories on the basis of market capitalization, large cap, medium cap and small cap. Each category consists of 38 companies. So for dividend announcement this sample is less, it is based on 70 companies, which have announced dividend regularly during the last years of data period. In this sample total number of announcements are 445 . Data sources are Website of Karachi Stock Exchange, Yahoo finance, Balance sheet analysis of SBP, Annual reports of companies and business recorder Pakistan is used.

Table 3.1.Type of industry, number of firms of earnings and dividend announcements.

\begin{tabular}{|c|c|c|}
\hline Type of Industry & NO. of Firms & NO. of Announcements \\
\hline Automobile and parts & 1 & 4 \\
\hline Automobile parts and Accessories & 4 & 20 \\
\hline Beverages & 2 & 8 \\
\hline cable and electrical goods & 3 & 12 \\
\hline Cement & 6 & 24 \\
\hline Chemical & 10 & 38 \\
\hline construction and material & 3 & 12 \\
\hline Electricity & 6 & 24 \\
\hline Food \& personal care products & 2 & 8 \\
\hline Food producer & 2 & 8 \\
\hline Forestry \& paper & 1 & 4 \\
\hline General industries & 5 & 20 \\
\hline Hospital & 1 & 4 \\
\hline House hold goods & 1 & 4 \\
\hline Industrial Engineering & 1 & 4 \\
\hline Industrial material and mining & 2 & 8 \\
\hline Industrial transportation & 1 & 4 \\
\hline Leisure goods & 1 & 4 \\
\hline Oil \& Gas exploration companies & 1 & 4 \\
\hline Oil \& gas Producer & 4 & 16 \\
\hline Oil and gas & 1 & 4 \\
\hline Personal goods & 10 & 39 \\
\hline Pharmaceuticals & 5 & 20 \\
\hline Refinery & 3 & 12 \\
\hline Sugar & 12 & 45 \\
\hline Technology and communication & 3 & 9 \\
\hline Textile Composite & 10 & 39 \\
\hline Textile Spinning & 6 & 23 \\
\hline Textile Weaving & 2 & 8 \\
\hline Tobacco & 1 & 4 \\
\hline Travel \& leisure & 2 & 8 \\
\hline Woollen & 1 & 4 \\
\hline Total & 114 & 445 \\
\hline
\end{tabular}




\section{METHODOLOGY}

The methodology used in this study is the standard event study methodology. The event window is used to show the impact before and after the event day to analyze how much the news is hold in the market and prices get affected. In the post event day the window is also generated. The managers of the firm have access to the internal information and can use this information before the others. In this study daily data is used for analysis and set the event window at twenty (20) days before and twenty (20) days after the earnings and dividend announcement day. The announcement day is represented by day zero (0).

$-20,-19,-18,-17,-16, \ldots \ldots-4,-3,-2,-1,0,+1,+2,+3,+4 \ldots+16,+17,+18,+19,+20$

Due to the abnormal nature of the information environment in developing stock markets, it is unlikely that the market reaction begin long before the actual announcements. The selection of a wide event window $($ of $-20,+20)$ is made in order to detain this potential pre and post-event reaction. Estimation window is 230 days before the event window.

Brown and Warner (1980) describe the market model as most flexible because it gives most reliable and well specified results in most of the conditions and daily stock return data was utilized in this study.

In the usual case it used in empirical research and statistical assumptions of the market model abnormal returns are reasonable to assume and practice. (MacKinlay, 1997).

\section{MODEL SPECIFICATION}

\subsection{Calculation of Expected Returns}

The market model is specified thus:

$E R i t=\alpha i+\beta i R m t+\varepsilon i t$

Where

$\mathrm{E}$ Rit $=$ returns on a stock $\mathrm{i}$ at time period $\mathrm{t}$

$\mathrm{R} m t=$ market return at time $\mathrm{t}$

$\varepsilon i t=$ error term

\subsection{Actual Returns}

The actual return of each stock is calculated for market model and 20 day window using the following formula.

$R_{i t}=\left(P_{i t}-P_{i t-1}\right) / P_{i t-1}$

Where

$$
\begin{aligned}
& R_{i t}=\text { Actual Return } \\
& P_{i t}=\text { The closing price of the stock I today } \\
& P_{i t-I}=\text { The closing price of the stock I previous day }
\end{aligned}
$$

\subsection{Return of Market}

In the same way the return of the market is calculated:

$$
\begin{gathered}
R_{m t}=\left(K S E_{t}-K S E_{t-1}\right) / K S E_{t-1} \\
\text { Where } \quad R_{m t}=\text { Market return on day t } \\
K S E_{t}=\text { KSE Index value today } \\
K S E_{t-l}=\text { KSE index value of previous day }
\end{gathered}
$$

\subsection{Abnormal Returns}

In order to analyse the behavior of market for the announcements, estimate abnormal returns (AR) at the time of the announcement, and pre and post the announcement. The abnormal return is find as:

$A R_{\mathrm{it}}=R_{i t}-\alpha-\beta \mathrm{iR}_{m t}$

The AR is the percentage change in share price less than or greater than what would normally be expected to occur. To enhance the capacity of informative analysis of the abnormal returns, ARs is average across the observations of all events, $\mathrm{N}$, using the model. 


\subsection{T-Statistics}

The ARs test for statistical significance using the t-statistic:

${ }_{t} \mathrm{AR}=\mathrm{AR}_{t} / \mathrm{SD}\left(\mathrm{AR}_{t}\right)$

Where $\mathrm{SD}(\mathrm{ARt})=$ standard deviation of ARt calculated over the estimation window.

The null hypothesis is calculated as mean abnormal return in the period surrounding the event day is zero. A mathematical justification of the hypothesis is provided under:

$$
\begin{aligned}
& \mathrm{H} 0: \mathrm{AR}=0 \\
& \mathrm{H} 1: \mathrm{AR} \neq 0
\end{aligned}
$$

Where; $\mathrm{AR}=$ Abnormal Returns

\subsection{Calculation of Cumulative Abnormal Return (CAR)}

In order to make generalizations and to draw an overall inference for the market reactions to earnings announcements, the cumulative abnormal returns (CARs) for the 41-day event window, from the start of the event period $\mathrm{t}-20($ day -20$)$ up to the time $\mathrm{t}+20($ day +20$)$ as follows:

$\mathrm{CAR}_{\mathrm{t}}=\Sigma \mathrm{AR}_{\mathrm{t}}$

\subsection{T-Statistics for Cumulative Abnormal Return (t-CAR)}

The CARs for each stock is calculated by summing abnormal returns (ARs) over the event window. Repeatedly we aggregate the CARs to gain the cumulative mean abnormal returns and then test for statistical significance by means of a similar t-statistic to the one we adopt for testing the statistical significance of abnormal returns. The new tstatistic is calculated thus:

${ }_{t} \mathrm{CAR}=\mathrm{CAR}_{t} / \mathrm{SD}\left(\mathrm{CAR}_{t}\right)$

Where $\mathrm{SD}(\mathrm{CAR} t)=$ standard deviation of CAR $t$ calculated over the event window.

\subsection{Calculation of Average Abnormal Return (AAR)}

Then the cross sectional average abnormal return at time ' $t$ ' is measured by averaging abnormal returns at day ' $t$ ' overall the firm of KSE all index.

$\mathrm{AAR}_{\mathrm{t}}=\Sigma 1 / \mathrm{N} \Sigma \mathrm{AR}_{\mathrm{t}}$

Where $\quad \Sigma \mathrm{AR}_{\mathrm{t}}=$ Sum of all Abnormal Returns

\subsection{Calculation of Cumulative Average Abnormal Return (CAAR)}

The cumulative average abnormal return was calculated by aggregating the Average Abnormal Return over the event window period

$\mathrm{CAAR}_{\mathrm{t}}=\Sigma 1 / \mathrm{N} \Sigma \mathrm{AAR}_{\mathrm{t}}$

Where $\quad \Sigma \mathrm{CAR}_{\mathrm{t}}=$ Sum of all Cumulative Abnormal Returns

\subsection{T-Statistics for Average Abnormal Return (t-AAR)}

Then t-statistics is used for checking the Average Abnormal Return on event day " $t$ ".

tAAR $=\frac{\text { AARt }}{\mathrm{S} / \sqrt{\mathrm{N}}}$

14.11. 3.3.11 T-Statistics for Cumulative Average Abnormal Return (T-CAAR)

And similarly to check the Cumulative Average Abnormal Return, the t-statistics is applied as fellow:

tCAAR $=\frac{\text { CAARt }}{\mathrm{S} / \sqrt{\mathrm{N}}}$

\section{Data Analysis And Discussion}

This section is divided into seven parts. First part shows the Average Abnormal Retrurns, Cumulative Average Abnormal Returns and T-Statistics for CAAR of Large Cap Earnings of KSE all index. Second part medium cap earnings. Third part small cap earnings. From fourth part, it consist on increase of earnings from last years. Fifth 
American Research Journal of Business and Management, Volume 1, Issue 2, 2015 ISSN 2379-1047

section shows the result decrease of earnings from previos year. Next part shows the results of constant earnings of both the years. Finally seventh part explain the results of dividend paying companies. All hypothesis are tested and their results are discussed in this chapter.

Table 4.1 AAR, CAAR and T-CAAR of Dividend Paying Companies of KSE all index

\begin{tabular}{|c|c|c|c|c|c|c|}
\hline Days & AAR & T-AAR & Decision & CAAR & T-CAAR & Decision \\
\hline-20 & 0.0029 & 0.2455 & Insignificant & 0.0029 & 0.2455 & Insignificant \\
\hline-19 & 0.0028 & 0.2328 & Insignificant & 0.0056 & 0.4695 & Insignificant \\
\hline-18 & 0.0040 & 0.3375 & Insignificant & 0.0095 & 0.8058 & Insignificant \\
\hline-17 & -0.0012 & -0.1024 & Insignificant & 0.0082 & 0.6930 & Insignificant \\
\hline-16 & 0.0004 & 0.0376 & Insignificant & 0.0086 & 0.7249 & Insignificant \\
\hline-15 & 0.0030 & 0.2504 & Insignificant & 0.0116 & 0.9808 & Insignificant \\
\hline-14 & 0.0040 & 0.3405 & Insignificant & 0.0156 & 1.3213 & Insignificant \\
\hline-13 & 0.0030 & 0.2504 & Insignificant & 0.0185 & 1.5662 & Insignificant \\
\hline-12 & -0.0002 & -0.0199 & Insignificant & 0.0183 & 1.5459 & Insignificant \\
\hline-11 & 0.0007 & 0.0617 & Insignificant & 0.0190 & 1.6081 & Insignificant \\
\hline-10 & -0.0021 & -0.1813 & Insignificant & 0.0169 & 1.4284 & Insignificant \\
\hline-9 & -0.0014 & -0.1179 & Insignificant & 0.0155 & 1.3074 & Insignificant \\
\hline-8 & 0.0029 & 0.2425 & Insignificant & 0.0184 & 1.5514 & Insignificant \\
\hline-7 & -0.0086 & -0.7258 & Insignificant & 0.0097 & 0.8187 & Insignificant \\
\hline-6 & -0.0122 & -1.0325 & Insignificant & -0.0025 & -0.2122 & Insignificant \\
\hline-5 & -0.0307 & -2.5963 & Significant & -0.0332 & -2.8040 & Significant \\
\hline-4 & -0.0135 & -1.1399 & Insignificant & -0.0464 & -3.9214 & Significant \\
\hline-3 & -0.0059 & -0.4996 & Insignificant & -0.0522 & -4.4104 & Significant \\
\hline-2 & 0.0002 & 0.0175 & Insignificant & -0.0519 & -4.3860 & Significant \\
\hline-1 & 0.0012 & 0.1010 & Insignificant & -0.0507 & -4.2815 & Significant \\
\hline 0 & -0.0036 & -0.3045 & Insignificant & -0.0542 & -4.5799 & Significant \\
\hline 1 & -0.0025 & -0.2095 & Insignificant & -0.0567 & -4.7878 & Significant \\
\hline 2 & -0.0026 & -0.2159 & Insignificant & -0.0591 & -4.9931 & Significant \\
\hline 3 & -0.0026 & -0.2215 & Insignificant & -0.0618 & -5.2214 & Significant \\
\hline 4 & -0.0012 & -0.0988 & Insignificant & -0.0631 & -5.3278 & Significant \\
\hline 5 & 0.0016 & 0.1339 & Insignificant & -0.0616 & -5.2065 & Significant \\
\hline 6 & 0.0008 & 0.0687 & Insignificant & -0.0608 & -5.1346 & Significant \\
\hline 7 & -0.0024 & -0.2050 & Insignificant & -0.0631 & -5.3326 & Significant \\
\hline 8 & 0.0015 & 0.1234 & Insignificant & -0.0616 & -5.2043 & Significant \\
\hline 9 & -0.0032 & -0.2723 & Insignificant & -0.0648 & -5.4740 & Significant \\
\hline 10 & 0.0022 & 0.1884 & Insignificant & -0.0625 & -5.2807 & Significant \\
\hline 11 & 0.0032 & 0.2665 & Insignificant & -0.0596 & -5.0301 & Significant \\
\hline 12 & 0.0064 & 0.5386 & Insignificant & -0.0534 & -4.5074 & Significant \\
\hline 13 & 0.0002 & 0.0189 & Insignificant & -0.0534 & -4.5078 & Significant \\
\hline 14 & 0.0039 & 0.3320 & Insignificant & -0.0496 & -4.1873 & Significant \\
\hline 15 & 0.0018 & 0.1483 & Insignificant & -0.0480 & -4.0511 & Significant \\
\hline 16 & 0.0013 & 0.1062 & Insignificant & -0.0466 & -3.9393 & Significant \\
\hline 17 & 0.0023 & 0.1902 & Insignificant & -0.0443 & -3.7417 & Significant \\
\hline 18 & 0.0002 & 0.0199 & Insignificant & -0.0440 & -3.7194 & Significant \\
\hline 19 & -0.0006 & -0.0481 & Insignificant & -0.0445 & -3.7594 & Significant \\
\hline 20 & -0.0013 & -0.1124 & Insignificant & -0.0458 & -3.8643 & Significant \\
\hline
\end{tabular}

Table 4.1 shows the impact of the dividend announcement on stock returns. On dividend announcement date, abnormal returns are negative but insignificant. $\mathrm{H}_{4}$ rejected because ARR and CAAR significantly different from zero. Returns before and after the dividend announcement are insignificant negative i-e there comes no change in share prices after the announcement as there was no change in dividend. Before one day of announcement AAR are positive and insignificant. Cumulative average abnormal returns are negative and insignificant before the six days of 
the announcement, but on -5 days it becomes significant and remained same at the end of the event window. CAAR values are negative after $3^{\text {rd }}$ day of the announcement and remain the same at $11^{\text {th }}$ day of the event.

Figure 4.1 CAAR of Dividend paying companies of KSE all index

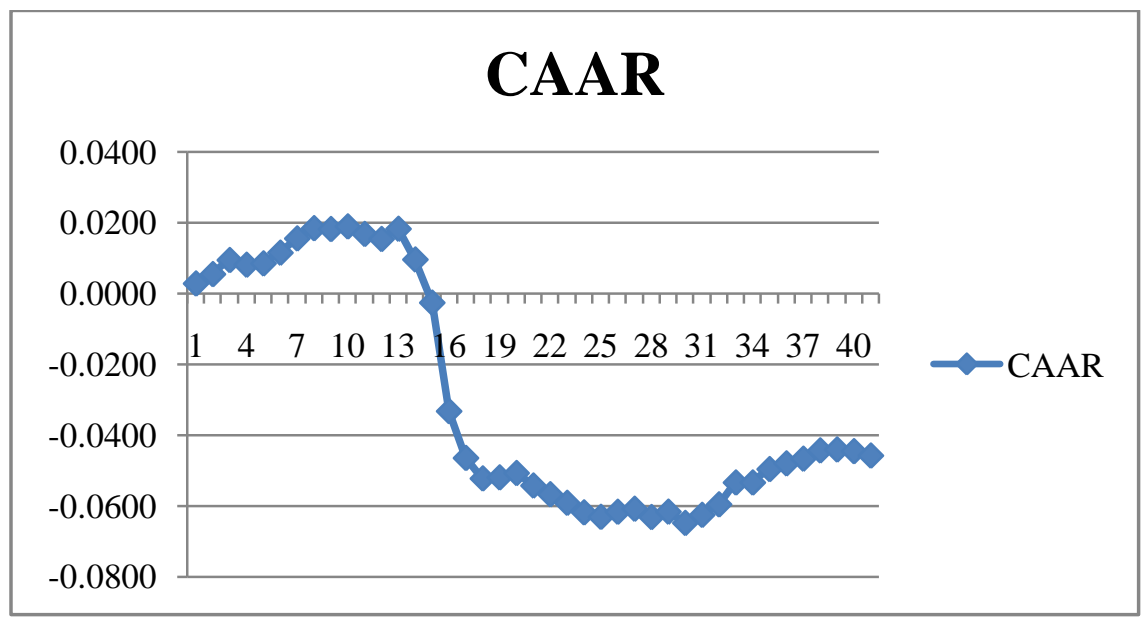

The above figure shows the values of cumulative average abnormal returns is positive before the announcement of earnings, but become negative on -5 days and on +3 to 11 days it is most negative and then gradually convert from negative to positive on the 11th day to onward. It shows the negative impact of dividend news on returns.

There are many points come out for arguments from the finding of this study. First, a general negative market response in the days surrounding the declaration of earnings and dividend is contrasting to the expectation because the study period, 2008 to 2012 coincided with the period of economic and financial crises.

The results, far from being convincing, could be an indication of the small intensity of investor literacy, which is feature of a distinctive Asian emerging market such as Pakistan. Reason is closely linked to the issue of delayed reactions prices, argument highlighted by Ball \& Kothari (1991) called a large transaction costs, trade and the poor distribution of information is a significant barrier in trade, thus preventing correct and complete response to the announcement of earnings. Moreover, it is the nature of companies listed on the KSE delay the opening of the annual profits, the rules are different.

According to Chambers \& Penman (1984), companies which announce earnings timely a positive signal created in the market and thus positive pre-announcement and post-announcement abnormal returns achieved. If thay delayed their earnings a negative signal created into the market. Therefore, these parameters can give some explanations found in the study. Second, the results show that the large extent of price reaction takes place in the preannouncement period. As Osei (2002) argued, emerging stock markets in Africa (with the possible exception of South Africa) due to the normal institutional it is known to be inefficient, infrastructural and regulatory weaknesses, including poor corporate governance practices, all of which join to a generate gap for asymmetrical access to information. Also, because the laws connecting to internal transactions known to be enforced, partly because of widespread corruption, the information environment allows a relatively high number of private acquisition of information and treat potential trade, officers, managers and others insiders.

The result shows that the reaction of prices is significantly before the announcement of earnings and dividend information may be documented. Third, the result opposite to the semi-strong form of EMH and it gives a small support to the behavioral school. There are many justification available for explanation of these findings. One, inadequate information about the security prices may lead to volatility in markets, on the basis of investor sentiments it would be result in the form of herding and investment behavior (Hirota \& Sunder, 2002). Two, it is common for companies which are listed on KSE, not release their earnings reports voluntarily and in a timely. This situation could ultimately lead to the approach of "herding" among investors, which in turn, can lead to significant price movements with a large and persistent across the date of disclosure of income.

At the end, for this sample of companies listed on KSE, findings shows that on the release of information about earnings and divedends the prices do not move randomly but exist a pattern. Althoug the results opposite to the efficient market hypothesis and provide some support to behavirol finance theory. Furthermore, the implications of these findings may confirm to be potentially applicable to subjects concerning the informational efficiency of stock 
markets domiciled in other developing Asian countries, and could potentially provide as a foundation for similar investigation in other stock markets across the border.

\section{Conclusion And Recommendation}

In this study it has observed the response and nature of the stock market on the release of companies annual earnings and dividends, listed on Karachi Stock Market. In particular, this study assesses the information, content and usability earnings releases to investors in the KSE, by measuring the rate of market reaction to corporate earnings information disclosure. According to the evidence documented in the existing literature, support the hypothesis that the information content obtained. However, the results of this study failed to find evidence that the efficiency of the stock price adjustment information in the announcement of earnings an dividend for the sample firms, as prices persist to drift 20 days after the date of the announcement. An observation that stock prices drift in the period after the announcement propose some support for the theory of behavioral finance.

Overall, the results of this study indicate that changes in stock prices in Pakistan in relation to earnings and dividend announcements, it is not random, but follow the pattern, which allows the negative abnormal returns are earned from trading around earnings and dividend announcement date. Analyses also concludes that positive and negative earning information disclosure are unable to influence the stock market effectively, and therefore cannot fully reflect the changes on the stock price, and investors can get the abnormal returns by using this earning information during whole event window. These finding contradicts the efficient markets hypothesis and is consistent with results from previous studies by Afego (2011), Olowe (1998), Oludoyi (1999) \& Adelegan (2009) which found the Nigerian stock market react inefficiently on the release of information. Karachi Stock Market also shows inefficiency on the release of earnings and dividends information. The evidence presented in this study brings to the fore a number of interesting questions which shows that a lot needs to be done, particularly by policy makers and regulators.

\section{RECOMMENDATIONS}

The first reference to the authorities monitor the activities of the market and the need to strengthen the ability to effectively deal with offenders. Sue (2003) explained that the reduction of inequalities in access to information assist to increase the confidence of investors and at the same time informative emerging markets stocks competitiveness and helps to improve the efficiency.

Second, companies should be encouraged to ensure timely release of their financial statements. Market regulators and policy makers require to force penalties on companies that delay the release of their results. According to Chambers \& Penman (1984), those companies which announced earnings later, negative signals is given to the participants of the market, and this may result in speculative investment behavior. When financial statements are timely release, it reduces and discourage unnecessary speculation by investors while it attracts investors, boosts liquidity and helps improve the effectiveness of the stock market.

Third, given the preponderance of uninformed people (and companies) to Karachi Stock Exchange, measures should be taken to implement educational programs to raise awareness of the activities of the stock market. Educating the public (individuals and corporations) the activities and benefits of participation in the equity markets are expected not only to attract a greater number of participants, but also to increase the liquidity (Yartey \& Adjasi, 2007). Moreover, the large foreign institutional investors should be attracted and encouraged to contribute in the Karachi stock market. The general consent is that institutional and global investors have a greater ability to make a comprehensive safety analysis.

In general, reducing the information asymmetry between market participants, the activities of institutional investors are expected to help improve the overall quality and the availability financial information environment of Karachi stock exchange. Moreover, these positive corporate governance practices of domestic companies, the rights of minority shareholders and the general market discipline and transparency are expected to have an impact on conservation.

\section{FUTURE RESEARCH}

At last, Given the relatively small sample and the results should be interpreted with caution. Future research may therefore be necessary to analyze a wider sample size to provide more comprehensive evidence. In addition, as this study is limited to one developing market, requires more analysis work being carried out similar to other developing markets in Asia to determine to what extent the results of this study are generalizable. Finally, the reaction of the stock price for interim reports and quarterly performance reports provide a potentially interesting path for future research in developing markets. 


\section{REFERENCES}

[1] Adelegan, O. J. (2001). Capital Market Efficiency and the Effects of Dividend Announcements on Share Prices. African Economic Research Consortium, 218-236.

[2] Adelegan, O.J. (2003). Capital Market Efficiency and the Effects of Dividend Announcement on Share Prices. African Development Review, Vol. 15 No. $2 \& 3$ pp: 218-236.

[3] Adelegan, O. J. (2004). How efficient is the Nigerian Stock Market: Further evidence. African Review of Finance and Banking, pp: 145-165.

[4] Adelegan, O. J. (2009). Price Reactions to Dividend Announcements. African Economic Research Consortium, Nairobi , 778-795.

[5] Ahmad, K. M., Ashraf, S., \& Ahmed, S. (2006). Testing Weak Form Efficiency for Indian Stock Markets. Economic and Political Weekly, Vol. 41, No. 1 pp. 49-56.

[6] Akbar, M., \& Baig, H. H. (2010). Reaction of Stock Prices to Dividend Announcements and Market Efficiency in Pakistan. The Lahore Journal of Economics, 103-125.

[7] Akintoye, I. R. (2008). Efficient Market Hypothesis and Behavioural Finance: A Review of Literature. European Journal of Social Sciences, Vol. 7, No. 2.

[8] Ali, M. B., \& Chowdhury, T. A. (2010). Effect of Dividend on Stock Price inEmerging Stock Market: A Study on the Listed Private Commercial Banks in DSE. International Journal of Economics and Finance, Vol. 2, No. 4.

[9] Azhagaiah, R., \& N, S. P. (2008). The Impact of Dividend Policy on Shareholders' Wealth. International Research Journal of Finance and Economics, 181-187.

[10] Below, S. D., \& Johnson, K. H. (1996). An Analysis Of Shareholder Reaction To Dividend Announcements In Bull And Bear Markets. Journal Of Financial And Strategic Decisions, Vol. 9 No. 3.

[11] Black, F., \& Scholes, M. (1974). The effects of dividend yield and dividend policy on common Stock prices and returns. Journal of financial Economics, 1(1), 1-22.

[12] Chambers, A.E. \& Penman S.H. (1984). Timeliness of reporting and the stock price reaction to earnings announcements. Journal of Accounting Research, pp.21-47.

[13] Campbell, K. (2009). The Stock Market Reaction to Stock Dividends and their Information Content. Journal of Accounting and Finance, 256-287.

[14] Chigozie, O. G. (2009). Analysis of Weak Form Efficiency in Nigerian Stock Market. The International Journal of Applied Economic and Finance.

[15] Easterbrook, H. (1984). Two Agency Cost Explanations of Dividends. The American Economic Review, 74, $650-659$.

[16] French, K.R. (1980). Stock returns and the weekend effect. Journal of Financial Economics, Vol.8, 55-69.

[17] Gordon, M. J. (1963). Dividends, Earnings, And Stock Prices. The Review of Economics and Statistics, Vol. 41, No. 2, pp. 99-105.

[18] Irum, M., Rafique, M., \& Hassan, A. (2012). Effect of Dividend Announcement on Share Prices of Petroleum Industry of Pakistan. Journal of Basic and Applied Scientific Research, 2(7)6503-6511.

[19] Jumah, A. H., \& Pacheco, C. J. (2008). The Financial Factors Influencing Cash Dividend Policy: A Sample Of U.S. Manufacturing Companies. Inter Metro Business Journal, Vol. 4 No. 2, p. 23.

[20] Lintner, J. (1956). Distribution of incomes of corporations among dividends, retained earnings and taxes. The American Economic Review, 46(2), 97-113.

[21] MacKinlay, A. C. (1997). Event studies in economics and finance. Journal of Economic Literature, Vol. 35, pp: 13-39.

[22] Mamun, A., Hoque, N., \& Mamun, A. M. (2013). Stock Price Reaction to Dividend Announcement: The Case of Bangladesh Capital Market. Journal of Economics and Sustainable Development, Vol. 4, No.8.

[23] Miller, M.H. \& Modigliani, F. (1961). Dividend policy, growth, and the valuation of shares. Journal of Business, Vol. 34, pp. 411-33. 